\title{
Pengaruh Modal Sendiri, Total Aset, Volume Usaha Dan Jumlah Anggota Terhadap Sisa Hasil Usaha (Shu) Pada Koperasi Di Kota Yogyakarta
}

\author{
Deny Ismanto \\ Program Studi Manajemen, Fakultas Ekonomi dan Bisnis Universitas Ahmad Dahlan \\ Email corresponding author: deny.ismanto@mgm.uad.ac.id
}

\begin{abstract}
ABSTRAK
Penelitian ini bertujuan untuk menganalisis pengaruh dari modal sendiri, total asetl, volume usaha dan jumlah anggota secara parsial maupun simultan terhadap sisa hasil usaha (SHU). Populasi dari penelitian ini adalah koperasi di Kota Yogyakarta. Teknik pengambilan sampel menggunakan metode purposive sampling, teknik pengumpulan data menggunakan dokumentasi serta teknik analisis data menggunakan metode regresi linear berganda. Luaran dalam penelitian ini adalah Jurnal Nasional dan Seminar. Hasil penelitian ini menemukan bahwa Modal sendiri tidak berpengaruh terhadap sisa hasil usaha (SHU) koperasi di Kota Yogyakarta. Total asset berpengaruh terhadap sisa hasil usaha (SHU). Volume usaha tidak berpengaruh terehadap sisa hasil usaha (SHU). Jumlah anggota tidak berpengaruh terhadap sisa hasil usaha (SHU). Modal sendiri, total asset, volume usaha dan jumlah anggota berpengaruh secara simultan terhadap sisa hasil usaha (SHU) koperasi di Kota Yogyakarta.
\end{abstract}

Kata Kunci: Modal sendiri, Total aset, Volume usaha, Jumlah anggota dan Sisa hasil usaha

\section{PENDAHULUAN}

Koperasi memiliki peran penting dalam terwujudnya kesejahteraan bagi anggota pada khususnya, dan masyarakat pada umumnya. Koperasi sekaligus sebagai gerakan ekonomi masyarakat yang berdasarkan atas asas kekeluargaan namun banyak masyarakat belum menyadari berapa besar pengaruh koperasi bagi perekonomian masyarakat.

Definisi koperasi menurut Undang-undang koperasi Nomor.25 Tahun 1992 "Koperasi adalah badan usaha yang beranggotakan orang-orang atau badan hukum koperasi dengan melandaskan kegiatannya berdasarkan prinsip koperasi sekaligus sebagai gerakan ekonomi rakyat yang berdasarkan asas kekeluargaan". Pembentukan koperasi pada awalnya bertujuan untuk memudahkan partisipasi para anggotanya untuk menyimpan dana dan meminjamnya kembali kepada anggotanya dengan jumlah bunga dan waktu yang telah disepakati. Sehingga koperasi diharapkan mampu memperoleh modal untuk membiayai kegiatan operasionalnya. Partomo S.T. dan Abdul Rahman S. (2002: 76), menyatakan bahwa, Perkembangan usaha koperasi sangat ditentukan oleh besar kecilnya dana atau Modal yang digunakan.

Lebih lanjut dikatakan bahwa semakin berkembangnya kegiatan usaha koperasi dewasa ini, maka semakin besarlah dana yang digunakan untuk membiayai kegiatan usaha koperasi. Hal ini berarti semakin besar pula tanggungjawab manajemennya. Faktor modal dalam usaha koperasi merupakan salah satu alat yang ikut menentukan maju mundurnya koperasi. Tanpa adanya modal, suatu usaha yang bersifat ekonomis tidak akan dapat berjalan sebagaimana mestinya. Menurut Andjar Pachta W, dkk (2005), faktor-faktor yang mempengaruhi SHU terdiri dari dua faktor yaitu faktor dalam dan faktor luar. Faktor dalam terdiri dari partisipasi anggota, jumlah modal sendiri, aset, kinerja pengurus, volume usaha, kinerja manajer serta kinerja karyawan. Faktor luarnya terdiri dari modal pinjaman dari luar, perilaku konsumen luar selain anggota dan pemerintah. 
Berdasarkan paparan diatas, maka dalam penelitian ini dapat dirumuskan beberapa rumusan masalah penelitian yaitu:

1) Apakah modal sendiri berpengaruh terhadap sisa hasil usaha (SHU) koperasi di Kota Yogyakarta?

2) Apakah total asset berpengaruh terhadap sisa hasil usaha (SHU) koperasi di Kota Yogyakarta?

3) Apakah volume usaha berpengaruh terehadap sisa hasil usaha (SHU) koperasi di Kota Yogyakarta?

4) Apakah jumlah anggota berpengaruh terhadap sisa hasil usaha (SHU) koperasi di Kota Yogyakarta?

\section{TINJAUAN PUSTAKA}

\subsection{Modal Sendiri}

Menurut Bambang Riyanto (2001: 240), modal sendiri pada dasarnya adalah modal yang berasal dari pemilik perusahaan yang tertanam di dalam perusahaan untuk waktu yang tidak tertentu lamanya. Menurut Andjar Pachta W. dkk (2005: 117), "Modal sendiri adalah modal yang berasal dari dana pendiri atau anggota koperasi yang disetorkan pertama kali, dalam bahasa teknis organisasi perusahaan biasanya disebut sebagai modal dasar pendirian koperasi". Jadi, modal sendiri adalah modal yang berasal dari perusahaan itu sendiri (misal cadangan laba) atau berasal dari pengambil bagian, peserta atau pemilik (modal saham, modal peserta, dan lain-lain). Secara umum, modal sendiri merupakan modal yang berasal dari para anggota koperasi itu sendiri yang terdiri atas simpanan pokok, simpanan wajib, dana cadangan, dan dana hibah. Modal sendiri bagi koperasi merupakan modal kerja untuk dapat menghasilkan laba dalam hal ini Sisa Hasil Usaha.

\subsection{Total Aset}

Sesuai dengan Standar Akuntansi Keuangan ETAP (2009), "Aset adalah sumber daya yang dikuasai entitas sebagai akibat dari peristiwa masa lalu dan dari mana manfaat ekonomi di masa depan diharapkan akan diperoleh entitas". Manfaat ekonomi masa depan yang terwujud dalam aset adalah potensi dari aset tersebut untuk memberikan sumbangan, baik langsung maupun tidak langsung, terhadap aliran kas dan setara kas kepada entitas. Beberapa aset, misalnya aset tetap memiliki bentuk fisik. Namun demikian bentuk fisik tersebut tidak esensial untuk menentukan eksistensi aset. Menurut Djarwanto PS. (2001: 15), "Aktiva merupakan bentuk dari penanaman modal perusahaan, bentuk-bentuknya dapat berupa harta kekayaan atau hak atas kekayaan atau jasa yang dimiliki perusahaan yang bersangkutan."

\subsection{Volume Usaha}

Menurut Suwandi (1988: 38), bahwa "Volume usaha merupakan totalitas kegiatan yang tercermin dalam bentuk nilai uang dan merupakan titik sentral dari interaksi dari berbagai peubah dalam koperasi sehingga volume usaha merupakan ukuran jumlah seluruh kegiatan yang diukur dalam satuan uang sekaligus dapat memberikan apa saja yang dilakukan koperasi selama kurun waktu tertentu". Aktivitas ekonomi koperasi pada hakekatnya dapat dilihat dari besarnya volume usaha koperasi tersebut. Kegiatan atau usaha yang dilakukan oleh koperasi bisa memberikan manfaat yang sebesar-besarnya terutama bagi anggota koperasi dan masyarakat pada umumnya. Usaha atau kegiatan yang dilakukan tersebut dapat dilihat dari besarnya volume usaha yang nantinya akan berpengaruh terhadap perolehan laba atau sisa hasil usaha koperasi (Arifin Sitio dan Halomon Tamba, 2001: 142). 


\subsection{Jumlah Anggota}

Sebagai suatu perkumpulan, koperasi tidak akan terbentuk tanpa anggota sebagai tulang punggungnya, semakin banyak anggota maka semakin kokoh kedudukan koperasi. Sebab badan usaha koperasi dikelola serta dibiayai oleh para anggota, hal ini terlihat dari pemasukan modal koperasi yang bersumber dari simpanan-simpanan para anggota, yang dikelompokkan sebagai modal sendiri atau modal equity. Disamping itu menurut ketentuan Pasal 26 ayat ( 1 ) UU No. 17 Tahun 2012, dinyatakan bahwa anggota koperasi Indonesia adalah merupakan pemilik sekaligus sebagai pengguna jasa koperasi. Di dalam ketentuan Pasal 26 ayat (3) UU No.17 Tahun 2012, dinyatakan bahwa keanggotaan koperasi bersifat terbuka bagi semua yang bisa dan mampu menggunakan jasa koperasi dan bersedia menerima tanggung jawab keanggotaan.

\subsection{Sisa Hasil Usaha (SHU)}

Menurut UU No. 17 Tahun 2012, SHU adalah surplus hasil usaha atau defisit hasil usaha yang diperoleh dari hasil usaha atau pendapatan koperasi dalam satu tahun buku setelah dikurangi dengan pengeluaran atas berbagai beban usaha. Menurut Andjar Pachta W,dkk (2005: 128), SHU merupakan laba atau keuntungan yang diperoleh dari menjalankan usaha sebagaimana layaknya sebuah perusahaan bukan koperasi. SHU tersebut merupakan hasil akhir dari komponen-komponen yang menghasilkan dikurangi dengan jumlah komponen-komponen biaya. Jadi dapat disimpulkan SHU merupakan laba atau pendapatan koperasi yang diperoleh dalam satu tahun buku setelah dikurangi dengan biaya, penyusutan dan biaya lainnya termasuk pajak dalam tahun buku yang bersangkutan.

\section{METODOLOGI PENELITIAN}

\subsection{Populasi, Sampel dan Teknik Sampel}

Populasi dalam penelitian ini adalah koperasi yang terdaftar di Kota Yogyakarta yang berjumlah 556 koperasi. Sampel dalam penelitian ini diambil dengan tehnik purposive sampling atau pemilihan sampel secara tidak acak yang informasinya diperoleh dengan menggunakan pertimbangan tertentu dimana umumya disesuaikan dengan tujuan atau masalah penelitian. Adapun yang dijadikan pertimbangan dalam pengambilan sampel adalah: (1) Memiliki Data Individu Tahunan Koperasi mengenai modal sendiri, total aset, volume usaha, jumlah anggota dan SHU selama periode penelitian, (2) Melaksanakan Rapat Anggota Tahunan (RAT) selama periode penelitian (3) Status koperasi aktif. Berdasarkan pertimbangan di atas maka didapat sebanyak 426 buah koperasi yang menjadi sampel.

\subsection{Sumber Data dan Teknik Pengumpulan Data}

Sumber data dalam penelitian ini adalah data sekunder. Pengertian dari data sekunder menurut Sugiyono (2010: 137) adalah "sumber data yang tidak langsung memberikan data kepada pengumpul data, misalnya lewat orang lain atau lewat dokumen". Data sekunder dalam penelitian ini diambil dari Laporan Tahunan Koperasi tahun 2015-2017. Teknik pengumpulan data menggunakan dokumentasi.

\subsection{Metode Analisis}

Pengujian hipotesis dilakukan secara multivariate dengan menggunakan regresi berganda. Regresi berganda digunakan dalam penelitian ini karena variabel bebasnya merupakan kombinasi antara metrik dan nominal (non-metrik) (Ghozali, 2007).

Model regresi berganda yang digunakan untuk menguji hipotesis sebagai berikut: 
$\mathrm{Y}=\beta 0+\beta 1 \mathrm{X} 1+\beta 2 \mathrm{X} 2+\beta 3 \mathrm{X} 3+\beta 3 \mathrm{X} 4+\mathrm{e}$

Keterangan :

$\mathrm{Y}=$ Sisa hasil usaha

$\mathrm{X} 1=$ Modal sendiri

$\mathrm{X} 2=$ Total aset

$\mathrm{X} 3$ = Volume usaha

$\mathrm{X} 4$ = Jumlah anggota

$\beta=$ Koefisien regresi

$\mathrm{e}=$ error

Untuk menguji hipotesis yang dikemukakan, maka digunakan uji t dan uji F. Uji t dimaksudkan untuk mengetahui variabel bebas (independen variabel) yang berpengaruh secara signifikan terhadap variabel terikat secara individual. Sedangkan uji $\mathrm{F}$ digunakan untuk mengetahui apakah secara simultan variabel-variabel bebas tersebut dapat menjelaskan variabel terikat.

\section{HASIL PENELITIAN DAN PEMBAHASAAN}

Persamaan Regresi Linear Berganda

Analisis regresi berganda ini menghasilkan koefisien-koefisien regresi yang menunjukkan arah hubungan sebab akibat antara variabel bebas dengan variabel terikat. Berdasarkan perhitungan persamaan regresi linier berganda dengan program SPSS, diperoleh output sebagai berikut:

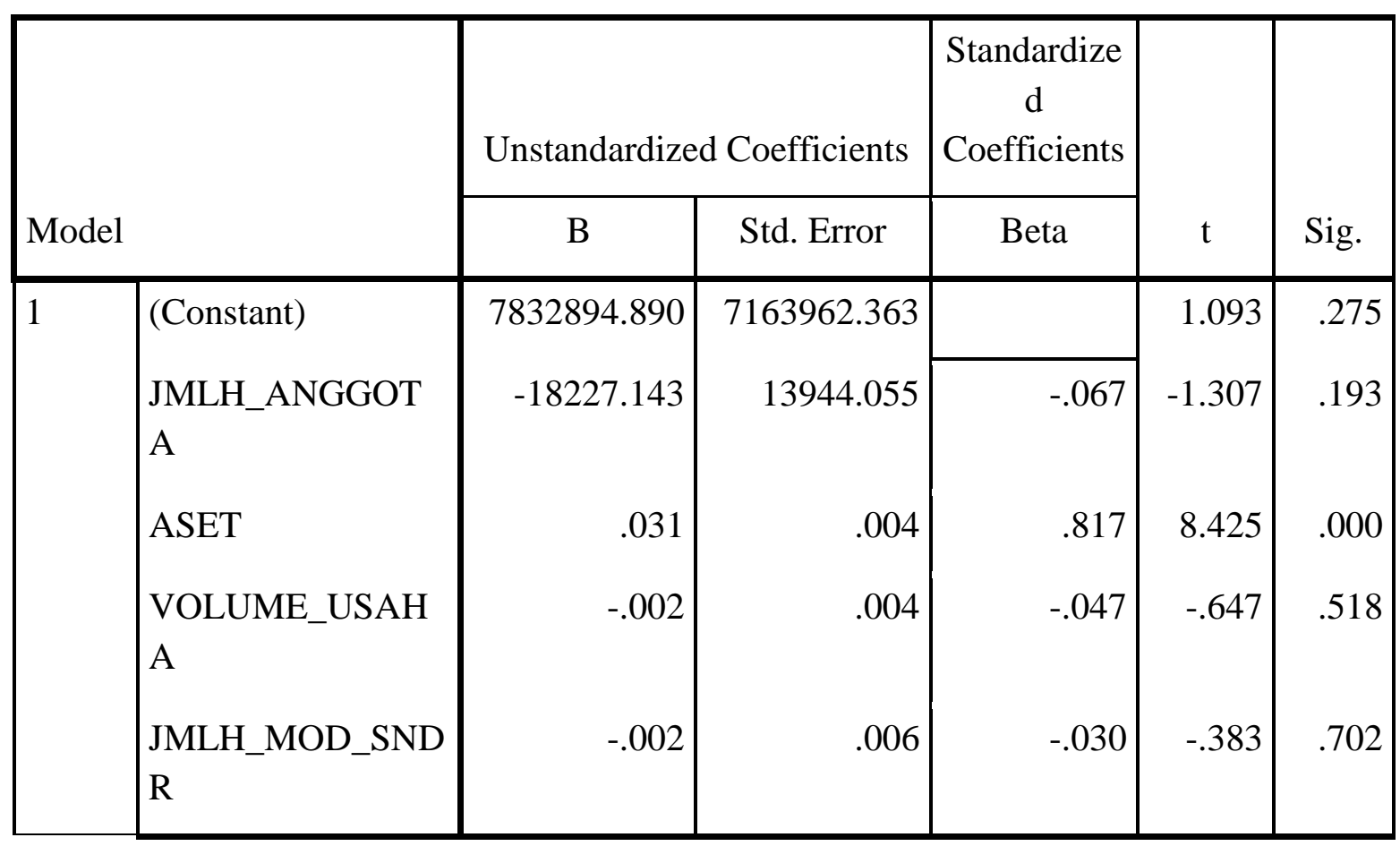

Berdasarkan tabel di atas, diperoleh persamaan sebagai berikut : $\mathrm{SHU}=7832894,89$ - 18227,14 jumlah anggota $+0,031$ aset $-0,002$ volume usaha $-0,002$ modal sendiri $+\mathrm{e}$.

\subsection{Uji Parsial (uji t)}

Pengujian variabel-variabel indenpenden secara individu, dilakukan untuk melihat pengaruh dari setiap variabel independen(Jumlah Anggota, Total Asset, Volume Usaha dan Modal Sendiri) terhadap variabel dependen (Sisa Hasil Usaha) dengan asumsi variabel independen yang lain konstan. Pengambilan keputusan didasarkan pada probabilitas signifikansi 0,05 atau 
(5\%). Berdasarkan pada hasil SPSS (lihat Tabel diatas) dapat dijelaskan pengaruh setiap variabel Jumlah Anggota, Total Asset, Volume Usaha dan Modal Sendiri terhadap Sisa Hasil Usaha secara parsial sebagai berikut : 1. Signifikansi Jumlah Anggota sebesar 0,193> 0,05, maka H0 diterima dan Ha ditolak, yang berarti Jumlah Anggota tidak berpengaruh secara parsial terhadap Sisa Hasil Usaha. 2. Signifikansi Aset sebesar 0,000 < 0,05, maka H0 ditolak dan Ha diterima, yang berarti Aset berpengaruh secara parsial terhadap Sisa Hasil Usaha. 3. Signifikansi Volume Usaha sebesar 0,518>0,05, maka H0 diterima dan Ha ditolak, yang berarti Volume Usaha tidak berpengaruh secara parsial terhadap Sisa Hasil Usaha. 4. Signifikansi Modal Sendiri sebesar 0,702 > 0,05, maka H0 diterima dan Ha ditolak, yang berarti Modal Sendiri tidak berpengaruh secara parsial terhadap Sisa Hasil Usaha.

\subsection{Uji Simultan (uji F)}

ANOVA $^{\mathrm{a}}$

\begin{tabular}{|c|c|c|c|c|c|}
\hline Model & $\begin{array}{l}\text { Sum of } \\
\text { Squares }\end{array}$ & $\overline{\mathrm{df}}$ & Mean Square & $\bar{F}$ & Sig. \\
\hline $\begin{array}{l}\text { Regression } \\
\text { Residual }\end{array}$ & $\begin{array}{r}1575020335 \\
999721980.0 \\
00 \\
1325849243 \\
030624770.0 \\
00 \\
030346800.0 \\
00\end{array}$ & 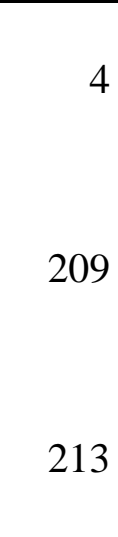 & $\begin{array}{r}3937550839 \\
99930500.00 \\
0 \\
6343776282 \\
443181.000\end{array}$ & 62.070 & $.000^{\mathrm{b}}$ \\
\hline
\end{tabular}

a. Dependent Variable: RES2

b. Predictors: (Constant), JMLH_MOD_SNDR, JMLH_ANGGOTA, VOLUME_USAHA, ASET

Berdasarkan pada hasil uji ANOVA dapat dikatakan bahwa seluruh variabel bebas (Jumlah Anggota, Total Asset, Volume Usaha dan Modal Sendiri) berpengaruh secara simultan (bersama-sama) terhadap Sisa Hasil Usaha. Hal ini dapat dilihat daritingkat signifikansi $F$ yang sebesar $0,000<0,05$.

\subsection{Uji Determinan}

\begin{tabular}{|l|r|r|r|r|}
\hline Model & R & R Square & \multicolumn{1}{c|}{$\begin{array}{c}\text { Adjusted R } \\
\text { Square }\end{array}$} & $\begin{array}{r}\text { Std. Error of } \\
\text { the Estimate }\end{array}$ \\
\hline 1 & $.737^{\mathrm{a}}$ & .543 & .534 & 79647826.602 \\
13
\end{tabular}

Berdasarkan tabel di atas, diketahui bahwa Korelasi antara Sisa Hasil Usaha dengan seluruh variabel bebas (Jumlah Anggota, Total Asset, Volume Usaha dan Modal Sendiri) adalah kuat 
karena $\mathrm{R}=0,737>0,5$. Sedangkan $\mathrm{R}$ Square menunjukkan angka sebesar 0,543 yang berarti 54,3\% perubahan Sisa Hasil Usaha disebabkan oleh (Jumlah Anggota, Total Asset, Volume Usaha dan Modal Sendiri). Sedangkan sisanya 46,7\% perubahan Sisa Hasil Usaha disebabkan oleh variabel-variabel lain yang tidak disertakandalam penelitian ini.

\section{KESIMPULAN DAN SARAN}

\subsection{Simpulan}

Berdasarkan analisis data dan pembahasan, maka penelitian ini dapat disimpulkan:

Modal sendiri tidak berpengaruh terhadap sisa hasil usaha (SHU) koperasi di Kota Yogyakarta. Total asset berpengaruh terhadap sisa hasil usaha (SHU) koperasi di Kota Yogyakarta. Volume usaha tidak berpengaruh terehadap sisa hasil usaha (SHU) koperasi di Kota Yogyakarta. Jumlah anggota tidak berpengaruh terhadap sisa hasil usaha (SHU) koperasi di Kota Yogyakarta. Modal sendiri, total asset, volume usaha dan jumlah anggota berpengaruh secara simultan terhadap sisa hasil usaha (SHU) koperasi di Kota Yogyakarta.

\subsection{Saran}

Hasil penelitian menunjukkan bahwa Total aset merupakan variabel yang paling dominan mempengaruhi Sisa Hasil Usaha, maka sebaiknya koperasi simpan pinjam di Kota Yogyakarta berusaha untuk meningkatkan Total Asset, seperti dengan cara meningkatkan simpanan wajib anggota, simpanan sukarela, maupun dapat melalui pihak ekternal koperasi seperti pinjaman dari perbankan atau pihak lain. Bagi peneliti selanjutnya disarankan untuk mengungkap variabel-variabel lain yang lebih banyak yang dapat mempengaruhi Sisa Hasil Usaha, tingkat suku bunga, dan lain-lain.

\section{DAFTAR PUSTAKA}

Ancok, D. (1989), "Validitas dan Reliabilitas Instrumen Penelitian," M. Singarimbun dan S. Effendi (ed.), Metodologi Penelitian, Survai, Yogyakarta : LP3ES. Januari. (1998), "Perguruan Tinggi Dalam Era Persaingan Bebas," Suara Pembaruan, 12

Arcaro, J.S. (1995), Quality in Education, Delray Beach : St. Lucie Press.

Azwar, S. (1997), Reliabilitas dan Validitas, Yogyakarta : Pustaka Pelajar.

Babbie, E. (1995), The Practice of Social Research, 7th ed., Belmaut : Wadsworth Publishing Company.

Badan Akreditasi Nasional Perguruan Tinggi, (1998), Akreditasi Program Studi Jenjang Sarjana (S1) hasil Penilaian Tahun 1996/1997, Direktori Umum Departemen Pendidikan dan Kebudayaan.

Bentler, P.M. dan G. Speckart (1979), "Models of Attitude Behavior Relations,: Psychological Review, Vol. 86, p. 452-464.

Bitner, M.J. (1990), "Evaluating Service Encounters : The Effects of Physical Surrounding and Employee Responses," Journal of Marketing, Vol. 55, April. P. 69-82.

Bolton, R.D. dan J.H. Drew (1991), “A Longitudinal Analysis of The Impact of Service Change on Customer Attitudes," Journal of Marketing, No. 55, January, p. 1-9. 
Brown, S.W. dan T.A. Swartz (1989), "A Gap Analysis of Professional Service Quality,” Journal of Marketing, Vol. 53, April, p. 92-98.

Carman, J.M. (1990), “Consumer Perceptions of Service Quality: An Assesment of The SERVQUAL Dimensions," Journal of Retailing, Spring, p.33-55. (1994), "SERVPERF Versus SERVQUAL : Reconciling Performance - Based and Perceptions

- minus - Expectations Measurement of Service Quality," Journal of Marketing, January, p. 1 